\title{
Literature review on success factors and methods used in warehouse location selection
}

\section{Depo yeri seçiminde kullanılan başarı faktörleri ve yöntemler üzerine bir literatür araștırması}

\author{
Ramazan Eyüp GERGINN+(iD), İskender PEKER ${ }^{2}$ (D) \\ 1Department of Transportation Services, Irfan Can Kose Vocational School, Gumushane University, Gumushane, Turkey. \\ reyupgergin@hotmail.com \\ 2Department of Disaster Management, Faculty of Economics and Administrative Sciences, Gumushane University, Turkey. \\ iskenderpeker@hotmail.com
}

\begin{abstract}
The fact that the production and consumption amounts are different from each other gives a dynamic feature to the concept of storage. In addition, an effective storage activity hinges upon the selection of the right warehouse location that takes into account capital and labor investments; minimizes the transportation cost and time. The aim of this study is to investigate the preliminary researches in the selection of the warehouse location selection and to present information on which success factors and methods are preferred. Within this scope, many academic studies have been examined by filtering various databases. According to the results of the study, the most used methods in warehouse location selection are multi-criteria decision making methods such as AHP, ANP and TOPSIS; and the most commonly used success factor is determined as the cost-based factors.
\end{abstract}

Keywords: Warehouse, Location selection, Literature review

\section{Introduction}

Increasing competitive pressures and performance requirements cause logistics activities to become more important, and companies need logistics to gain competitive advantage and build sustainable customer relationships. In recent years, this need felt by companies has increased their commitment to logistics and supply chain management.

One of the key activities of logistics and supply chain management is storage. Storage includes all movements of goods in the warehouse or distribution, including receipt, storage, order collection, accumulation, sorting, and distribution [1]. The warehouse is the intermediate point that plays a strategic role in the realization of an entire sequence of operations which is from the raw material stage to the production environment and distribution to the consumption centers [2]. In real life, the concept of storage will keep updating as production and consumption quantities are constantly differentiated. In addition to this global aspect of warehousing, the fact that warehouses usually require large capital investments and labor costs, and the need to minimize transportation cost and time [3] make the choice of storage location more strategic.

The problem of warehouse location selection is the process of determining the size and number of storage centers in order to meet the demands of demand centers. It is important to determine the appropriate warehouse location in order to

\section{Öz}

Dünya üzerinde üretim ve tüketim miktarlarının birbirlerinden farklı olması depolama kavramına dinamik bir özellik kazandırmaktadır. Ayrıca etkin bir depolama faaliyeti; sermaye ve işçilik yatırımlarını dikkate alacak, tașıma maliyet ve zamanını minimize edecek doğru depo yerinin seçilmesinden geçmektedir. Bu doğrultuda çalışmanın amacl, depo yeri seçiminde yapılmış olan öncül araştırmaların incelenmesi ve depo yer seçiminde hangi başarı faktörleri ve yöntemlerin tercih edildiğine dair bir bilgi sunmaktır. Bu amaç kapsamında çok sayıda akademik çalıșma çeșitli veri tabanları süzülerek incelenmiştir. Çalışmanın sonuçlarına göre depo yer seçiminde en fazla kullanılan yöntemler AHP, ANP ve TOPSIS'in bașını çektiği Çok Kriterli Karar Verme yöntemleri, en çok kullanılan başarı faktörü ise Maliyet içerikli faktörler olarak belirlenmiştir.

Anahtar kelimeler: Depo, Yer seçimi, Literatür araştırması

improve the efficiency of physical distribution and minimize the total cost. For this reason, it is a priority condition that the success factors and methods to be used in the selection of the warehouse location are determined correctly. In this study, a research has been carried out in which the method and success factors used in warehouse location selection are investigated in depth. In addition, explanatory information is given about the years of these studies and the scientific journals they published. For this purpose, research methodology has been included in the following section of the study. Review of the literature presented in Section 3. In the last section, the results about the study are discussed, and research gaps and recommendations for researches are identified.

\section{Research methodology}

The proposed research methodology is consisting of two steps. The first step of the methodology is called by "data collection approach" that explains how the papers are identified. Data analysis approach is the second steps of the methodology which categorized papers according to their methodology, subject etc.

\subsection{Data collection approach}

Warehouse site selection has become a matter of interest for many researchers from past to present [4]. The studies in the research between 1996-2019 have appeared in the Web of Science and Scopus databases. In addition, some national articles have been searched and explored from different 
databases such as Google Scholar, YOK theses, ULAKBIM. Books have not been included into the study.

The search terms were defined inductively, after reading multiple papers in the Location selection and Warehouse Management. We finally used the following keywords:

$$
\begin{aligned}
& \text { "Warehouse Location Selection" } \\
& \text { "Warehouse Location Decision" } \\
& \text { "Storage Location Selection" } \\
& \text { "Storage Location Decision" } \\
& \text { "Warehouse Site Selection" } \\
& \text { "Storage Site Selection" }
\end{aligned}
$$

\subsection{Data analysis approach}

120 articles yielded of our search. We consider "The study only focuses on the optimal location selection of warehouses". At the end of the process 50 paper kept this condition and take into the consideration. It can be stated that warehouse location selection is aimed in all of these studies.

When these studies are evaluated in general, it can be stated that multi-criteria decision making, fuzzy logic, statistical analysis, linear and mathematical programming, heuristic and meta-heuristic methods and the other decision support systems methods are utilized to determine appropriate location of warehouses.

Moreover these studies are published in decision making journals such as "International Journal of Management Mathematics", "Expert System with Applications", transportation and logistics journals such as "Transportation Research Procedia", "Transportation Research Part E", "Tunneling and Underground Space Technology", "Supply Chain Management: An International Journal", "Waste Management ", "Research in Transportation Economics", and "The Asian Journal of Shipping and Logistics" and the other interdisciplinary journals such as "International Journal of Production Economics", "European Journal of Operational Research", "International Journal of Business and Management", Journal of Environmental Management" etc.

Furthermore, the success factors of "costs, infrastructure, accessibility, reliability, flexibility etc. are commonly taken into the consideration in most of the studies. Details of the information are provided in the following steps.

\section{Review of the literature}

In this research, preliminary studies on warehouse location selection are reviewed in four sub-titles which are review papers, journals/conferences they published, success factors and methods they used, respectively. The explanatory information on the studies is shown in Tables and Figures below.

\subsection{Review papers}

Among literature reviews, studies can be summarized according to their advantages, disadvantages and originality as follows:

[4] determined the optimal number and locations of warehouses in Nepal for a humanitarian relief chain. The contribution of the study is limited except for the additional constraints included to modelling and solution technique. [5] presented an integrated approach to the warehouse site selection process by taken into account both qualitative and quantitative factors. [6] proposed a simulation based approach to the large-scale of uncapacitated warehouse location problems in the real world on a digital map by balloon search which is a new heuristic algorithm. The efficiency of expanding the Balloon is not so clear in the given problem instance. [7] solved the uncapacitated warehouse location problem by a new hybrid approach which includes Simple Genetic Algorithm and Add-Heuristic. [8] presented A Geographic Information Systems aided to the warehouse location selection process. The model can be used for site assessment by personnel who has knowledge of site selection theory. [9] concerned with the optimal location of a central warehouse by the traditional model that minimize total transportation costs. Model only takes in to the account the inventory and service costs. [10] utilized a software to select public warehouse location according to several criteria and exploit a database when some data are missing. [11] evaluated uncapacitated warehouse location problem by Tabu-Search algorithm. The algorithm finds optimal solutions very quickly and high frequencies to all benchmarks. [12] identified the important factors which multinational companies decide the locations of their regional distribution centers by a careful review and summary of relevant literatures and structured questionnaire-based survey of distribution managers of North American Companies. [13] focused on the design of an underground warehousing logistics center of Athens by using the Room and Pillar Mining Method. The proposed model is underlining the feasibility of the plan and show that is a very attractive investment. [14] considered different formulation styles which are Sharma and Geoffrion \& Graves for the multistage warehouse location problem. [15] provided a detailed description of how the AHP method is implemented in analyzing the decision by using Fortune 500's company to evaluate outsourcing location decision. The research implies that AHP may be more applicable in these areas. [16] introduced the factors which influence the decision process of the warehouse location selection by Gravity Model approach and AHP. [17] investigated three aspects of fuzzy decision making procedure from a foreign market for international distribution centers selection problems by Fuzzy Factor Rating Systems and Group Decision Making process. [18] applied Analytic Network Process (ANP) to select the best location of a municipal solid waste plant in Valencia. In this paper two decision analysis models (hierarchy and network based model) are used. According to results of the study network based model is better because it allows technicians to analyze the influences among the different criteria. As future work, ANP/BOCR analysis can be used to improve the decision making process. [19] presented a new Local Search approach to select the appropriate location of uncapacitated warehouse location problem. The algorithm is very simple. The disadvantage of the algorithm is the exponential growth of its computation time with the problem size. [20] showed a successful application of multi-criteria Choquet Integral which considers interactions between criteria to a real warehouse location selection problem of a big Turkish logistic firm. For future work, Fuzzy ANP can be used and the obtained results can be compared with this study.

[21] proposed a modified Fuzzy TOPSIS method to select appropriate site for municipal solid waste. This proposed methodology can be utilized for any site selection problem which handles qualitative data. [22] addressed the problem of an optimal location selection for an international distribution center. Fuzzy DEMATEL, ANP and TOPSIS methods are used to 
determine the best location. The results show that the proposed method is effective. For future studies the proposed hybrid method can be applied to other problems such as project selection, material selection or strategy selection etc. [23] compared advantages and disadvantages of AHP, TOPSIS, ELECTRE and Grey Theory in the application of the warehouse selection problem. When using TOPSIS and ELECTRE methods, criteria have been evaluated parallel to two basic purposes of maximization and minimization. But some criteria like stock holding capacity had to define a certain lower limit and an optimum value and an upper limit. At this point Grey Theory is useful and utilized in this study. [26] applied a preference method for selecting optimal city distribution locations in urbanized areas. This study was carried out without considering traffic real time state from the truck present location point to the transshipment location point, traffic jam, road construction, incidents etc. [27] proposed an approach which comprises two stages. In the first stage the criteria for warehouse location selection has identified. In the second stage Fuzzy TOPSIS is used to generate aggregate scores selection of best alternative. The limitation of the study is not to take into account the interaction between the criteria. [29] developed a model which consists three different methods (AHP, VIKOR and MOORA) to determine the best location of warehouses. [30] investigated the factors affecting the location selection at the intra-urban level and their degree of importance by logistic regression model in Istanbul. According to the model, industrial clusters made a positive impact while service sector made negative on the location selection of warehouses.

[31] evaluated optimal locations of a new banana distribution warehouse by AHP. The model is very effective, but has some limitations such as not taking into account the interaction between the criteria. [32] presented a math-heuristic model for the warehouse location routing problem in disaster relief. The solution approach is capable of solving larger instances. This model can be improved by stochastic model in the future work. [34] proposed three extended fuzzy multi-criteria decision making methodologies (TOPSIS, SAW and MOORA) to select the best location of warehouses. The study has two limitations that could be addressed in future research. First, it cannot be applied to heterogeneous decision making environment and second, the success factors are independent. [36] focused to minimized the total inbound and outbound transportation costs and the total warehouse costs by nonlinear mixed integer programming. The results show that the model is appropriate for the small and medium size problem not available for large size problems. [37] addressed the problem of selecting the optimal location of warehouses by multi criteria decision making approach for manufacturing companies. [39] developed a non-linear program to estimate the location of a warehouse in Bangkok. The main strength of the model is the inclusion of transportation costs. [41] determined locations of disaster response distribution centers by a multiple objective mathematical programming. This solution method cannot be used in real life situations, whereas heuristic approach may be more useful. [44] proposed a generic framework for optimal location selection of a joint distribution center. It helps governments and enterprise managers make scientific decisions. It is the first study that take into consideration the detailed list of evaluation criteria for location selection of a joint distribution center. [45] wanted to determine the efficient location of warehouses in the logistics network by genetic algorithm. This model does not guarantee the optimal solution, but sub-optimal. [49] aimed to identify the suitable prepositioned warehouse location for international humanitarian relief organizations by Fuzzy AHP and Fuzzy TOPSIS. This study contributed to the literature by considering detailed warehouse location selection factors. [50] illustrated the selection of suitable location of warehouses in Special Economic and Free Trade Zones by Fuzzy AHP. This study considered a limited number of criteria. [51] utilized Euclidean Distance Linearization to determine the optimal location of warehouses. The model has two advantages; first, it is easy to trap into local optimal and second, it is sensitive to initial locations. This study is the first to bring up this issue by comparison between the traditional solutions and the truly optimized one for warehouse location selection.

\subsection{Journals/conferences}

The list of the Journals/Conferences in which studies are published are presented in Table and Figure 1.

Table 1: Information of the Journal/Conferences and Thesis.

\begin{tabular}{|c|c|}
\hline Study & Journal/Conferences/Thesis \\
\hline [4] & Transportation Research Procedia \\
\hline [5] & International Journal of Production Economics \\
\hline [6] & Proceedings of the 29th Conference on Winter Simulation \\
\hline [7] & $\begin{array}{l}\text { XV. ECPD International Conference on Material Handling and } \\
\text { Warehousing }\end{array}$ \\
\hline [8] & International Journal of Production Economics \\
\hline [9] & IMA Journal of Management Mathematics \\
\hline$[10]$ & European Journal of Operational Research \\
\hline$[11]$ & European Journal of Operational Research \\
\hline [12] & Transportation Research Part E \\
\hline$[13]$ & Tunneling and Underground Space Technology \\
\hline [14] & European Journal of Operational Research \\
\hline [15] & Supply Chain Management: An International Journal \\
\hline [16] & International Journal of Business and Management \\
\hline [17] & Expert Systems with Applications \\
\hline [18] & Journal of Environmental Management \\
\hline [19] & Computers \& Industrial Engineering \\
\hline$[20]$ & Expert Systems with Applications \\
\hline$[21]$ & Waste Management \\
\hline [22] & Expert Systems with Applications \\
\hline$[23]$ & Expert Systems with Applications \\
\hline$[24]$ & Doctoral Thesis \\
\hline$[25]$ & XI. ISPR \\
\hline [26] & Procedia - Social and Behavioral Sciences \\
\hline$[27]$ & Interdisciplinary Journal of Contemporary Research in Business \\
\hline [28] & Master Thesis \\
\hline [29] & Journal Of Industrial Engineering \\
\hline$[30]$ & European Planning Studies \\
\hline$[31]$ & Computers and Electronics in Agriculture \\
\hline$[32]$ & Computers \&Operations Research \\
\hline [33] & Transportation Research Procedia \\
\hline [34] & $\begin{array}{l}\text { International Journal of Management Science and Engineering } \\
\text { Management }\end{array}$ \\
\hline [35] & Procedia - Social and Behavioral Sciences \\
\hline [36] & Computers \&Operations Research \\
\hline [37] & Advances in Industrial Engineering and Management \\
\hline [38] & Decision Science Letters \\
\hline [39] & Journal of Social Sciences \\
\hline [40] & JEBPIR \\
\hline$[41]$ & IFAC-Papers On Line \\
\hline [42] & Research in Transportation Economics \\
\hline [43] & Computers \& Industrial Engineering \\
\hline [44] & Transportation Research Part D \\
\hline$[45]$ & Procedia Engineering \\
\hline$[46]$ & Neural Computing and Applications \\
\hline [47] & Neural Computing and Applications \\
\hline$[48]$ & Expert Systems With Applications \\
\hline [49] & The Asian Journal of Shipping and Logistics \\
\hline [50] & IIMB Management Review \\
\hline$[51]$ & Computers \& Industrial Engineering \\
\hline
\end{tabular}


The graph of the Journals/Conferences in which studies are published are presented in Figure 1.

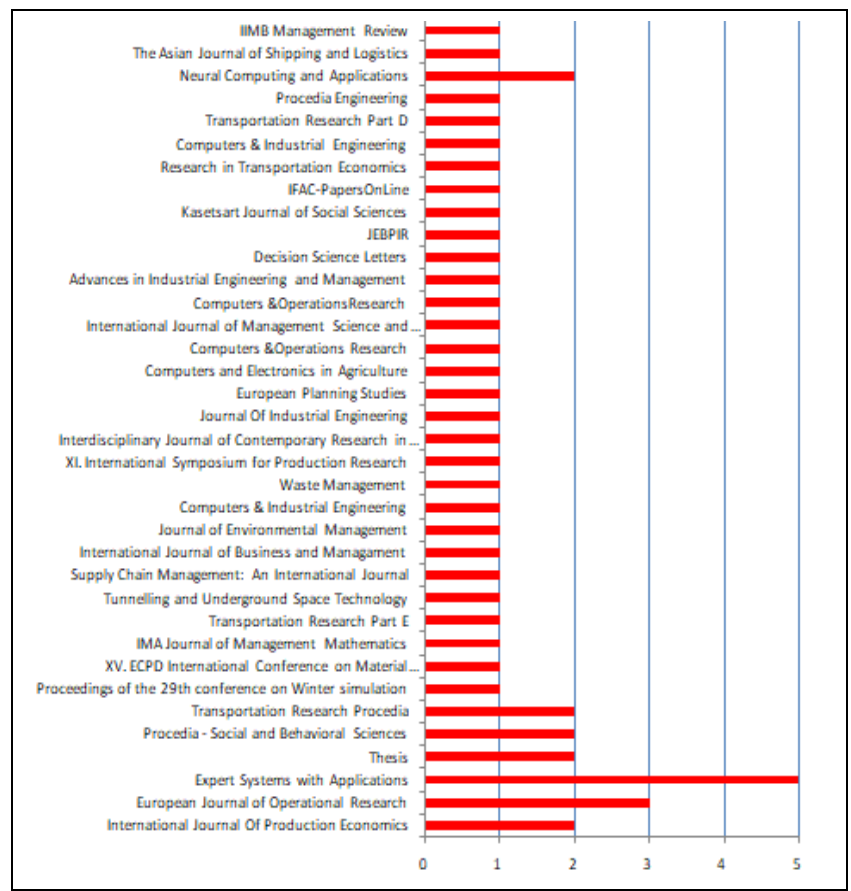

Figure 1: The graph of Journal/Conferences.

According to Table and Figure 1, it can be stated that the studies have taken place in 35 different journals/conferences. "Expert Systems with Applications" and "European Journal of Operational Research" are the most commonly published journals.

\subsection{Appropriate methods of warehouse location selection}

The methods used in these studies are shown in Table and Figure 2.

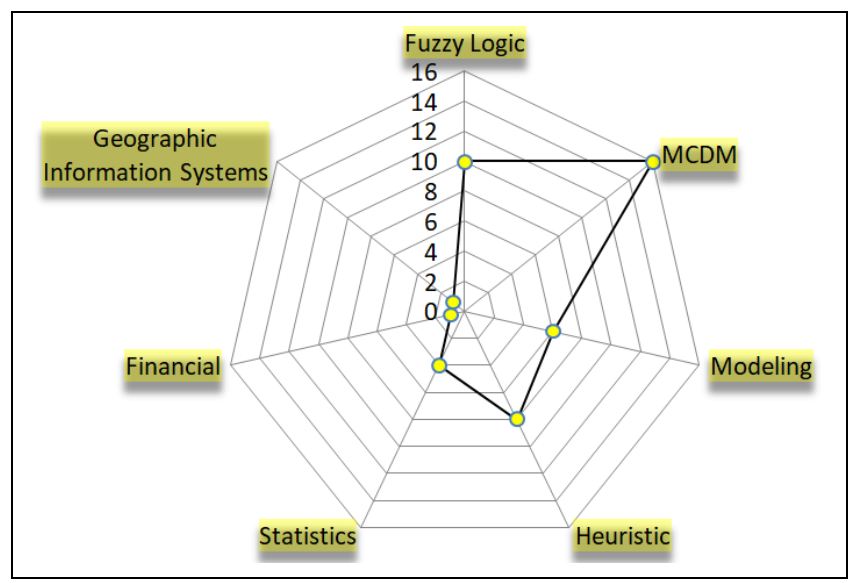

Figure 2: Spread of studies by methods.

Table and Figure 2 show that Multi Criteria Decision Making (MCDM) methods are preferred more than the others.

As can be seen in Figure 3, there has been a significant increase in recent years in the studies related to the warehouse location selection process.

Figure 4 shows the spread of the methods on a yearly basis.
Table 2: The methods of the studies.

\begin{tabular}{|c|c|}
\hline Study & Methods \\
\hline [4] & Mathematical Modeling \\
\hline [5] & AHP \\
\hline [6] & Ballon Search \\
\hline [7] & Genetic Algorithm \\
\hline [8] & Geographical Decision Support System \\
\hline [9] & Mathematical Modeling \\
\hline [10] & MCDM \\
\hline [11] & TABU Search \\
\hline [12] & Mean and Chi-Square Test \\
\hline [13] & Evaluation of Cost Analysis and Investment Plans \\
\hline [14] & Linear Programming \\
\hline [15] & AHP \\
\hline [16] & Centro baric Method and AHP \\
\hline$[17]$ & Fuzzy Logic \\
\hline [18] & ANP \\
\hline [19] & Intuitive Local Search \\
\hline [20] & Choquet Integral \\
\hline [21] & AHP/TOPSIS \\
\hline [22] & AHP/ ANP/ Fuzzy DEMATEL \\
\hline [23] & Simos Procedure/ TOPSIS/ ELECTRE/GRA \\
\hline [24] & Mixed Integer Modeling \\
\hline$[25]$ & Genetic Algorithm \\
\hline$[26]$ & AHP/ TOPSIS/ Entropy \\
\hline [27] & Fuzzy TOPSIS \\
\hline [28] & Choquet Integral \\
\hline [29] & AHP/ VIKOR/ MOORA \\
\hline [30] & Logistics Regression \\
\hline [31] & AHP \\
\hline [32] & Mixed Integer Linear Programming \\
\hline [33] & P-Median Myopic Algorithm \\
\hline [34] & TOPSIS/ BAT/ MOORA \\
\hline [35] & Mean / Standard Deviation \\
\hline [36] & Nonlinear Mixed Integer Programming \\
\hline [37] & VIKOR/TOPSIS/GRA \\
\hline [38] & AHP/TOPSIS \\
\hline [39] & Nonlinear Mathematical Modeling \\
\hline [40] & AHP/BAT/COPRAS/MOORA \\
\hline$[41]$ & Multi-Purpose Decision Model \\
\hline$[42]$ & Identifying Critical Factors \\
\hline$[43]$ & $\begin{array}{l}\text { SAW/ MOORA/TOPSIS/ VIKOR/ELECTRE II/ } \\
\text { COPRAS/PROMETHEE }\end{array}$ \\
\hline$[44]$ & Fuzzy AHP/ Fuzzy Entropy/ Fuzzy TOPSIS \\
\hline [45] & Genetic Algorithm \\
\hline [46] & Interval Valued Fuzzy Decision \\
\hline [47] & Interval Valued Hesitant Fuzzy Pair-wise \\
\hline [48] & Comparison Kendall's Tau-b / \\
\hline [49] & Spearman's RHO Test/Fuzzy AHP/ Fuzzy TOPSIS \\
\hline [50] & Fuzzy AHP \\
\hline [51] & Mathematical Programming \\
\hline
\end{tabular}

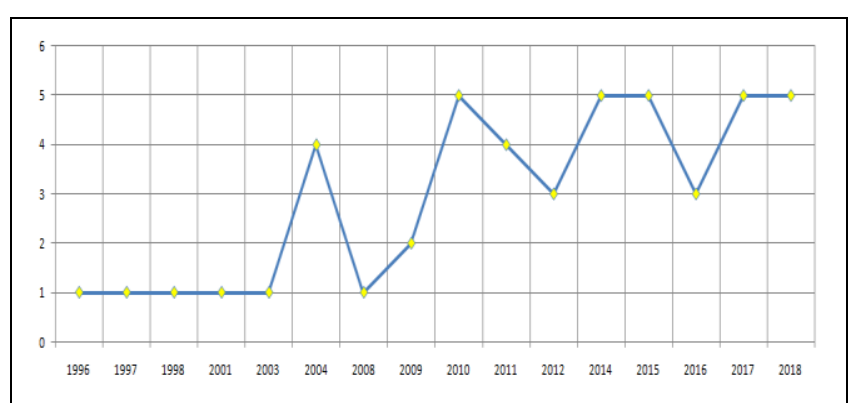

Figure 3: Spread of Studies by years. 


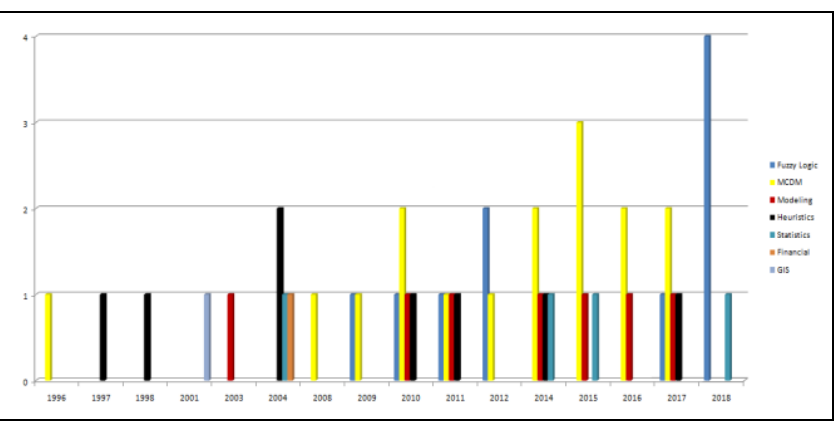

Figure 4: Spread of methods on a yearly basis.
According to the graphs above, it has been determined that MCDM methods are frequently preferred in recent years and in many studies they have been used as a support method in determining the weights of success factors. When the studies are evaluated in general, it is seen that the most widely used method related to warehouse location selection is MCDM methods.

\subsection{Success Factors of warehouse location selection}

Findings related to success factors are presented in Table 3.

Table 3: Success factors of warehouse location selection.

\begin{tabular}{|c|c|c|}
\hline Study & Main-Criteria & Sub-Criterion \\
\hline \multirow[t]{2}{*}{ [4] } & - & *Demand and Candidate Point *Distance*Accessibility *Development Index *Disaster Safety Index \\
\hline & *Reliability & *Obedience*Truth*Transportation*Plant *Personnel Abilities *Non Damage Handling \\
\hline \multirow{2}{*}{ [5] } & *Flexibility & *Special Requests *Urgent Deliveries*Capacity \\
\hline & *Strategic Alignment & *Strategic Alliances *Strategic Alignment *Collaboration \\
\hline [6] & - & ${ }^{*}$ Transportation Costs *Warehouse Candidate Locations *Warehouse Fixed Costs \\
\hline \multirow[t]{2}{*}{ [7] } & - & ${ }^{*}$ Candidate Warehouse Location ${ }^{*}$ Consumers $*$ Fixed Costs ${ }^{*}$ Customer Request \\
\hline & - & $\begin{array}{c}\text { * Customer Population *Spending Power *Quality of Transportation Links *Competition *Store Size } \\
\text { *Parking Facilities *On-Site *Warehouse Management Costs *Distribution Costs }\end{array}$ \\
\hline \multirow{3}{*}{ [8] } & - & $\begin{array}{c}\text { *Unit Product Price *Unit Shipping Costs *Variable Order Costs *Holding Costs Ratio *Stock Holding Costs Ratio } \\
\text { *Reorder Costs Ratio }\end{array}$ \\
\hline & *Buildings & $\begin{array}{l}\text { *Storage Volume }\left(\mathrm{m}^{3}\right) * \text { Insulated Roof and Walls *Existing Offices in the Area *Distance to Road*Railway } \\
\text { Connection *Waterway Connection *Daily Hour of Work }\end{array}$ \\
\hline & ${ }^{*}$ Customs & ${ }^{*}$ Customs in the Area *Bonded Warehouse *Artificial Warehouse \\
\hline \multirow[t]{2}{*}[10]{} & *Logistics & $\begin{array}{c}\text { *Stores Account *Inventory Management *Using Barcode or Label *Computer Systems *RF Communication * } \\
\text { Repackaging *Order Management }{ }^{*} \text { Transportation/Distribution }\end{array}$ \\
\hline & * Handling & $\begin{array}{l}\text { *Mixed Transmission*Electric Forklift *Diesel/Gasoline Forklift *Loading / Unloading Docks *Dock Levelling } \\
\text { *Automatic Dock *Semi-Trailer Docks }\end{array}$ \\
\hline \multirow[t]{2}{*}[11]{} & - & * Fixed Costs * Tran \\
\hline & & ${ }^{*}$ Transportation Connection and Market Access * Transportatio \\
\hline \multirow[t]{2}{*}{ [12] } & - & $\begin{array}{c}\text { Availability and Price *Corporation Income Tax Incentive *BIT/E-Business Infrastructure *Logistics Services } \\
\text { Providers and Costs *Income Tax for Foreign Labors }\end{array}$ \\
\hline & *Site Selection & *Field Selection *Substructure * Underground Gap Tr \\
\hline \multirow{3}{*}{$\begin{array}{l}{[13]} \\
{[14]}\end{array}$} & *Financial Analysis & $\begin{array}{l}\text { *Surface Land Acquisition *Underground Area Creation *Waterproof *Floor *Networks *Fire Protection and } \\
\text { Security *Systems *Offices *Ramps *Unforeseen Costs }\end{array}$ \\
\hline & - & *Warehouse Location Costs *Transportation Costs \\
\hline & *Technical Ability & $\begin{array}{l}{ }^{*} \text { Performance Standards *Ascension and Transfers *Forecast Management *Telecommunication *Training } \\
\text { *Knowledge and Ability *Products *Incentives *Quality Management *Loss of Employee }\end{array}$ \\
\hline \multirow[t]{2}{*}{ [15] } & *Experience & $\begin{array}{l}\text { *Background *Property Diversity *Financial Power *Facilities *Professional Cooperation *Staff Relationships } \\
\text { *Emergency Plan }\end{array}$ \\
\hline & *External Abilities & *International Infrastructure *Language Skills *Facility Security*Environmental Risk-Safety Assessment \\
\hline [16] & - & ${ }^{*}$ Distribution of Sales Place ${ }^{*}$ Transportation $*$ Land $*$ Political Environment $*$ Natural Enviro \\
\hline \multirow[t]{2}{*}{ [17] } & - & $\begin{array}{l}{ }^{*} \text { Service *Transportation and Distribution Systems *Market Potential *Cultural Issues *Environmental Factors } \\
\text { *Infrastructure }\end{array}$ \\
\hline & *Facility Usage Costs & $\begin{array}{c}\text { *Distance to Waste Water Treatment Plant *Distance to Another Waste Collection Plant *Distance to Waste } \\
\text { Landfill *Municipalities and Waste Disposal }\end{array}$ \\
\hline \multirow[t]{3}{*}{ [18] } & $\begin{array}{l}\text { *Facilities and } \\
\text { Infrastructure }\end{array}$ & ${ }^{*}$ Access *Water *Flow and Sewerage Systems *Power *Paths \\
\hline & $\begin{array}{l}\text { *Environmental } \\
\text { Problems }\end{array}$ & $\begin{array}{c}\text { *Water Resources *Visual Impact *Affected Community *Topography *Cattle Routes *Archaeological Areas } \\
\text { *Flood Areas *Protected Areas }\end{array}$ \\
\hline & *Legal Requirements & ${ }^{*}$ Land Planning *Facilities and Infrastructure *Environmental Issues *Near Municipalities \\
\hline \multirow[t]{3}{*}{ [19] } & - & *Fixed Costs *Transportation Costs \\
\hline & *Costs & ${ }^{*}$ Labor Force ${ }^{*}$ Transportation *Tax Incentives and Structures *Financial Incentives *Handling Costs \\
\hline & $\begin{array}{l}\text { *Workforce } \\
\text { Specificity }\end{array}$ & *Labor Force Ability *Access to Labor \\
\hline \multirow[t]{3}{*}[20]{} & *Infrastructure & $\begin{array}{c}* \text { Presence and Mode of Transportation * Systems of Telecommunication * Transportation Modes Quality and } \\
\text { Reliability }\end{array}$ \\
\hline & *Markets & *Distance to Customer/ Suppliers / Producers * Times and Response of Delivery \\
\hline & *Macro Environment & vernment Policies *Industrial Regulation Laws *Reconstruction and Construction Plan \\
\hline
\end{tabular}


Table 3: Continued.

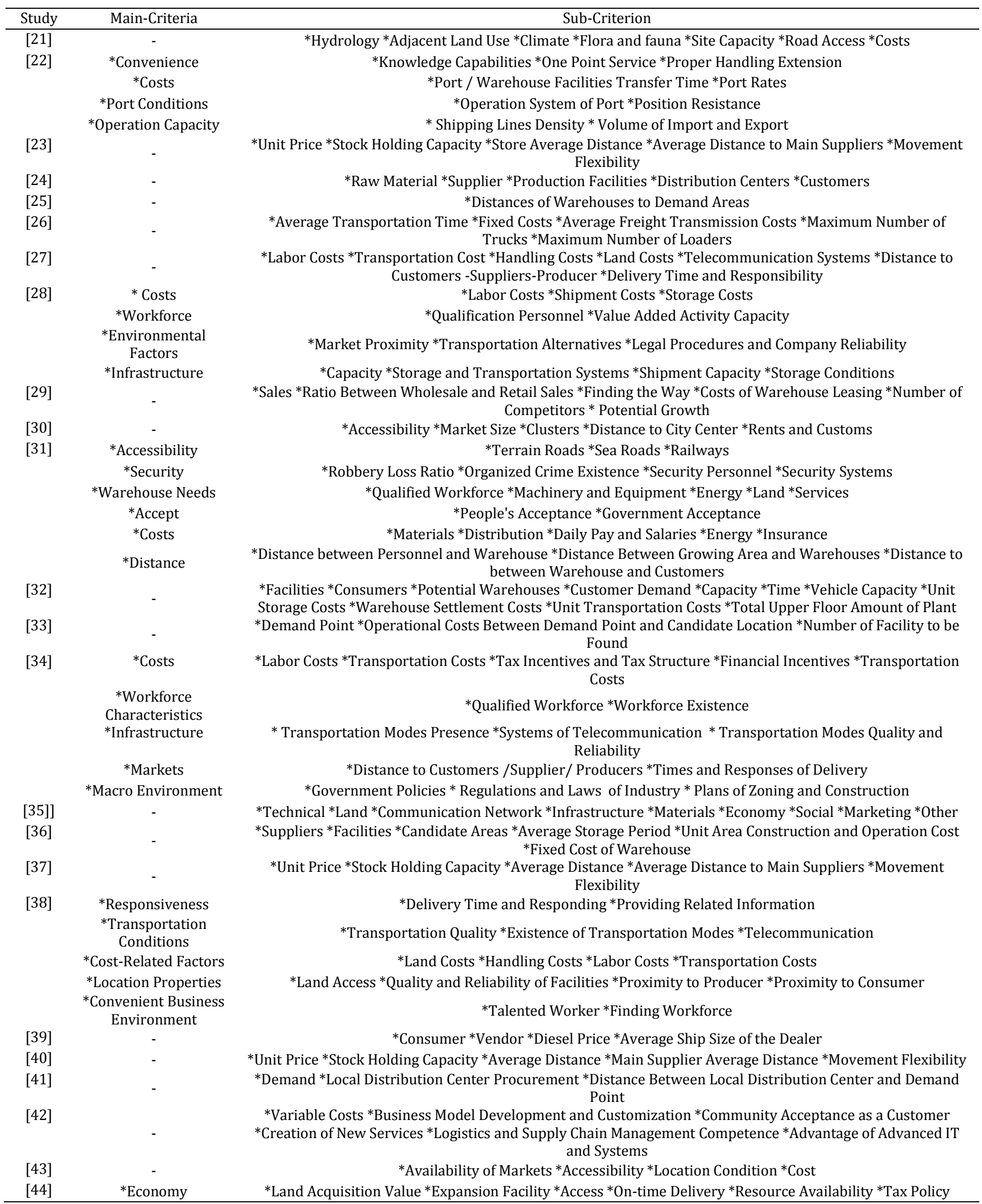


Table 3: Continued.

\begin{tabular}{|c|c|c|}
\hline Study & Main-Criteria & Sub-Criterion \\
\hline \multirow[b]{3}{*}{ [45] } & *Society & $\begin{array}{l}{ }^{*} \text { Impact on Traffic Accidents }{ }^{*} \text { Impact on Residents Near }{ }^{*} \text { Contribution to the Development of Leading Industry } \\
\qquad \text { Harmonization with Regional Economic Planning }\end{array}$ \\
\hline & *Environment & *Impact on Ecological Landscape *Environmental Protection Level *Natural Conditions \\
\hline & - & $\begin{array}{c}\text { *Transportation Costs *Fuel Costs *Additional Costs Related to Warehouse *Distance and Relation of } \\
\text { Warehouse to Railway and Highway Infrastructure }\end{array}$ \\
\hline [46] & - & ${ }^{*}$ Costs $*$ Labor $*$ Transportation ${ }^{*}$ Environment $*$ Geographical Location \\
\hline \multirow[t]{5}{*}{ [47] } & ${ }^{*}$ Costs & *Labor *Land ${ }^{*}$ Transportation *Financial Incentives \\
\hline & *Markets & $\begin{array}{c}\text { * Time in Cross-Dock and Customers * Time in Cross-Dock and Suppliers * Cross-Dock to Terminal time } \\
{ }^{*} \text { Availability of Utilities }\end{array}$ \\
\hline & $\begin{array}{l}* \text { Government } \\
\text { Influence }\end{array}$ & ${ }^{*}$ Laws $*$ Restrictions and Policies \\
\hline & *Infrastructure & * Transportation Modes Quality and Reliability *Systems of Telecommunication \\
\hline & *Labor Resource & *Level of Skill * Labor Availability \\
\hline$[48]$ & - & $\begin{array}{l}\text { *Price of Purchase *Manufacturer’s Warranty of Manufacturer *Service Network *Spare Parts Availability } \\
\text { *Average Cost of Maintenance * Consumption of Fuel *Max Bearing Capacity *Max Lifting Capacity * Forklift } \\
\text { Movement Speed *Speed of Lifting/Lowering }\end{array}$ \\
\hline \multirow[t]{4}{*}{ [49] } & *Location & $\begin{array}{l}\text { *Geographical Location *Distance to beneficiaries * Free Location's Disaster *Donor's Opinion Climate } \\
\text { *Distance to Other Warehouses *Distance to Disaster Prone Areas }\end{array}$ \\
\hline & *National Stability & *Political , Economical and Social Stability \\
\hline & *Cost & ${ }^{*}$ Storage ${ }^{*}$ Logistics $*$ Replenishment ${ }^{*}$ Labor *Land \\
\hline & $\begin{array}{l}{ }^{*} \text { Cooperation } \\
{ }^{*} \text { Logistics }\end{array}$ & $\begin{array}{l}\text { *Host Government *United Nations *Neighbor Countries *Logistics Agents *NGO's } \\
\text { *Airport *Seaport *Road *Warehouse }\end{array}$ \\
\hline \multirow[t]{3}{*}[50]{} & *Infrastructure & ${ }^{*}$ Transportation and Connectivity *Electricity and Water Supply *IT and Telecommunication Setup \\
\hline & *Government & *Land Cost * Policies of Taxation *Incentives \\
\hline & *Market & *Size *Distance to Main Market *Scope for Market Growth \\
\hline$[51]$ & & *Distance to Market "Transportation Costs \\
\hline
\end{tabular}

Based on Table 3, it can be stated that the cost related factors are the front plan. In addition, "Infrastructure, Transportation, Workforce, Transportation Modes and Handling" success factors are often preferred.

\section{Discussion and Conclusion}

The success of storage, which is one of the critical activities of logistics and supply chain management, depends on the appropriate location selection of the warehouse [3]. The aim of the current study is to analyze in depth the research conducted regarding the warehouse location selection which is an important task for the optimization of logistics systems [20].

The related studies in warehouse location selection literature can be classified as distribution, production and contract type warehouses [1]. Distribution type warehouses; [4],[8],[9],[12], [13],[16],[17],[22],[26],[33]-[35],[39],[41],[42],[44],,[46]-[48], [52] are to store various products from different suppliers, and for different customers. Production type warehouses; [5],[7],[20],[23],[27],[29],[31],[36]-[38],[50],[53] are for products with different characteristics in a production facility. Contract type warehouses; [6],[10],[11],[15],[18],[21],[30], $[32],[45],[49]$ are to carry out warehousing for different customers.

The methods used in the selection of warehouse location such as multi criteria decision making techniques [5],[10],[15],[18], [21]-[23],[26],[29],[31],[34],[37],[38],[40],[43], fuzzy logic [17],[27],[44],[46],[47],[49],[50], statistical analysis [12],[16], [30],[33],[35],[48],[49], non/linear and mathematical programming [4],[9],[14],[20],[24],[28],[32],[36],[39],[51], heuristic and meta heuristic methods [6],[7],[11],[19],[25],[45] and other decision support systems [8],[13],[23],[41],[42] are useful for all types of warehouses.
A similar situation arises when the success factors are taken into consideration. That is, even if the type of warehouse is differentiated, the criteria considered are similar. On the other hand, the most commonly used success factors are distance to demand center/consumer etc [4],[10],[18],[23]-[25],[27],[29], [33],[39],[41],[45],[49],[51], accessibility and flexibility (location, transportation connection, land availability [4]-[7], [10],[12],[13],[18],[20],[30],[31],[40],[43],[44],[47]-[49], costs (transportation, warehouse management, distribution, shipping, order, fixed, labor, handling, storage, settlement, tax incentives and structure) [6]-[9],[11]-[14],[19]-[22],[26]-[28], [31],[32],[34],[36],[38],[39],[42]-[49], infrastructure (logistics, information technology, capacity, storage conditions etc.) $[10],[15],[17],[28],[31],[34],[35],[42],[45],[47],[50] \quad$ and environmental factors (natural and political environment, market size) [16],[17],[28],[35],[44],[47],[50]. In other words these success factors of warehouse location selection are useful for all types of warehouses.

The increase in the number of warehouse location studies by years shows that the warehouse location selection process is important, and the awareness of this importance has been increasing. "Expert Systems with Applications" is identified as the most widely available resource among the published sources of the studies examined in the research. This result is an important indicator of scientific journals in which researchers of warehouse site selection studies can publish their work. The most commonly used success factor in the studies is the "Costs" related factors. The fact that depots usually need large capital investments and labor costs [3] can be expressed as the main reason for the frequent use of success factors in costs. Other success factors most used in the studies are; Infrastructure, Transportation, Transportation, Workforce, Transportation Modes, and Handling. MCDM 
methods are mostly used in studies related to warehouse location selection. When the related literature is examined, it is revealed that the MCDM methods are the most integrated methods with other methods. In addition, when the most preferred methods among the methods of MCDM are considered, it can be stated that AHP, ANP, and TOPSIS are in the forefront, respectively. This tendency towards MCDM can be explained with the influence of qualitative and quantitative variables in warehouse location selection. In that, the MCDM methods give the ability to evaluate qualitative and quantitative variables together with the expert opinions.

The study was based on the database of Web of Science and Scopus and any year restriction was not used. Future studies, can be done based on journals and expanded databases, and a more in-depth research can be carried out by reaching the studies conducted within specified years. Moreover, since the warehouse location selection is closely related to the warehouse design, success factors planned together with warehouse design with warehouse location can be developed in future studies. Finally, Geographical Information Systems (GIS) and MCDM methods in warehouse location; and Simulation in warehouse design can be preferred.

\section{References}

[1] Onut S, Tuzkaya UR, Dogac B. "A particle swarm optimization algorithm for the multiple-level warehouse layout design problem". Computers \& Industrial Engineering, 54, 783-799, 2008.

[2] Keskin MH. Lojistik Tedarik Zinciri Yönetimi. 2. Baskı. Ankara, Türkiye, 2008.

[3] Çakmak E., Günay NS, Aybakan G, Tanyaș M. "Determining the size and design of flow type and U type warehouses". Procedia - Social and Behavioral Sciences, 58, 1425-1433, 2012.

[4] Maharjan R, Hanaoka S. "Warehouse location determination for humanitarian relief distribution in nepal”. Transportation Research Procedia, 25, 1151-1163, 2017.

[5] Korpela J, Tuominen M. "A decision aid in warehouse site selection". International Journal of Production Economics, 45, 169-180, 1996.

[6] Hidaka K, Okano H. "Simulation-Based approach to the warehouse location problem for a large-scale real instance". Proceedings of the 1997 Winter Simulation Conference, Atlanta, Georgia, USA, 1997.

[7] Kratica J, Tosic D, Filipovic V. "Solving the Uncapacitated warehouse location problem by SGA with Add-Heuristic". $X V$. ECPD International Conference on Material Handling and Warehousing, Belgrade, Serbia, 09-10 December 1998.

[8] Vlachopoulou M, Silleos G, Manthou V. "Geographic information systems in warehouse site selection decisions". International Journal of Production Economics, 71, 205-212, 2001.

[9] Drezner Z, Scott C, Song JS. "The central warehouse location problem revisited". IMA Journal of Management Mathematics, 14(4), 321-336, 2003.

[10] Colson G, Dorigo F. "A public warehouses selection support system". European Journal of Operational Research, 153, 332-349, 2004.
[11] Michel L, Van Hentenryck P. "A simple tabu search for warehouse location". European Journal of Operational Research, 157(3), 576-591, 2004.

[12] Oum P, Park JH. "Multinational firms' location preference for regional distribution centers: Focus on the northeast asian region". Transportation Research Part E, 40, 101-121, 2004.

[13] Zevgolis IE, Mavrikos AA, Kaliampakos DC. "Construction, storage capacity and economics of an underground warehousing-logistics center in Athens, Greece". Tunneling and Underground Space Technology, 19, 165-173, 2004.

[14] Sharma RRK, Berry V. "Developing new formulations and relaxations of single stage capacitated warehouse location problem (SSCWLP): Empirical investigation for assessing relative strengths and computational effort". European Journal of Operational Research, 177(2), 803-812, 2007.

[15] Liu LB, Berger P, Zeng A, Gerstenfeld A. "Applying the analytic hierarchy process to the offshore outsourcing location decision". Supply Chain Management: An International Journal,13 (6), 435-449, 2008.

[16] Chen, C. "A decision model of field depot location based on the centrobaric method and analytic hierarchy process (AHP)". International Journal of Business and Managament, 4(7), 71-75, 2009.

[17] Ou CW, Chou SY. "International distribution center selection from a foreign market perspective using a weighted fuzzy factor rating system". Expert Systems with Applications, 36, 1773-1782, 2009.

[18] Beltran PA, Ferrando JPP, Garcia FG, Agulio AP. "An analytic network process approach for siting a municipal solid waste plant in the metropolitan area of Valencia (Spain)". Journal of Environmental Management, 91, 1071-1086, 2010.

[19] Cura, T. "A parallel local search approach to solving the uncapacitated warehouse location problem". Computers \& Industrial Engineering, 59, 1000-1009, 2010.

[20] Demirel T, Demirel NÇ, Kahraman C. "Multi-Criteria warehouse location selection using choquet integral". Expert Systems with Applications, 37, 3943-3952, 2010.

[21] Ekmekcioglu M, Kaya T, Kahraman C. "Fuzzy multicriteria disposal method and site selection for municipal solid waste". Waste Management, 30(8-9), 1729-1736, 2010.

[22] Kuo MS. "Optimal location selection for an international distribution center by using a new hybrid method". Expert Systems with Applications, 38, 7208-7221, 2011.

[23] Ozcan T, Celebi N, Esnaf S. "Comparative analysis of multi criteria decision making methodologies and implementation of a warehouse location selection problem". Expert Systems with Applications, 38, 9773-9779, 2011.

[24] Ozesenli ON. Tedarik Zinciri Yönetiminde Optimal Depo Yeri Seçimi, Doktora Tezi, Yıldız Teknik Üniversitesi, İstanbul, Türkiye, 2011.

[25] Yilmaz B, Dagdeviren M, Akcayol MA. "Hızlı tüketim malları depo yeri seçimi problemi için genetik algoritma ile bir çözüm". XI. Üretim Araștırmaları Sempozyumu, İstanbul, Türkiye, 23-24 Haziran 2011.

[26] Bu L, Van Duin JHR, Wiegmans B, Luo Z, Yin C. "Selection of city distribution locations in urbanized areas". Procedia-Social and Behavioral Sciences, 39, 556-567, 2012. 
[27] Ashrafzadeh M, Rafiei FM, Isfahani NM, ZareZ. "Application of fuzzy TOPSIS method for the selection of warehouse location: A case study". Interdisciplinary Journal of Contemporary Research in Business, 3(9), 655-671, 2012.

[28] Caka, E. Tedarik Zinciri Yönetiminde Choquet Integral Yöntemi ile Depo Yeri Seçimi. Yüksek Lisans Tezi, İstanbul Teknik Üniversitesi, İstanbul, Türkiye, 2012.

[29] Aktepe A, ErsozS. "AHP-VIKOR ve MOORA yöntemlerinin depo yeri seçim probleminde uygulanması". Journal of Industrial Engineering (Turkish Chamber of Mechanical Engineers), 25(1-2), 2-15, 2014.

[30] Durmus A, Turk SS. "Factors influencing location selection of warehouses at the intra-urban level: Istanbul case". European Planning Studies, 22(2), 268-292, 2014.

[31] Garcia JL, Alvarado A, Blanco J, Jimenez E, Maldonado AA, Cortes G. "Multi-Attribute evaluation and selection of sites for agricultural product warehouses based on an analytic hierarchy process". Computers and Electronics in Agriculture, 100, 60-69, 2014.

[32] Rath S, Gutjahr WJ. "A math-heuristic for the warehouse location-routing problem in disaster relief". Computers \&Operations Research, 42, 25-39, 2014.

[33] Segura E, Benitez RBC, Lozano A. "Dynamic location of distribution centres, a real case study". Transportation Research Procedia, 3, 547-554, 2014.

[34] Dey B, Bairagi B, Sarkar B, Sanyal SK. "Warehouse location selection by fuzzy multi-criteria decision making methodologies based on subjective and objective criteria". International Journal of Management Science and Engineering Management, 11(4), 1-17, 2015.

[35] Chotithammaporn W, Sannok R, Mekhum W, Rungsrisawat S, Poonpetpun P, Wongleedee K. "The development of physical distribution center in marketing for small and micro community enterprise (SMCE) product in Bangkontee, Samut Songkram". Procedia Social and Behavioral Sciences, 207, 121-124, (2015).

[36] Huang S, Wang Q, Batta R, Nagi R. "An integrated model for site selection and space determination of warehouses". Computers \& Operations Research, 62, 169-176, 2015.

[37] Jayant A. "Use of grey relational analysis in solving multiple attribute decision-making problem: A case study of warehouse location selection". Advances in Industrial Engineering and Management, 4 (2), 157-164, 2015.

[38] Karmaker C, Saha M. "Optimization of warehouse location through fuzzy multi-criteria decision making methods". Decision Science Letters, 4(3), 315-334, 2015.

[39] Monthatipkul, C. "A non-linear program to find an approximate location of a second warehouse: A case study". Kasetsart Journal of Social Sciences, 37, 190-201, 2016.
[40] Ozbek A, Erol E. "COPRAS ve MOORA yöntemlerinin depo yeri seçim problemine uygulanması". JEBPIR, 2(1), 23-42, 2016.

[41] Yılmaz H, Kabak O. "A multiple objective mathematical program to determine locations of disaster response distribution centers". IFAC-PapersOnline, 49(12), 520-525, 2016.

[42] Björklund M, Abrahamsson M, Johansson H. "Critical factors for viable business models for urban consolidation centres". Research in Transportation Economics, 64, 36-47, 2017.

[43] Dey B, Bairagi B, Sarkar B, Sanyal SK. "Group heterogeneity in multi member decision making model with an application to warehouse location selection in a supply chain". Computers \& Industrial Engineering, 105, 101-122, 2017.

[44] He Y, Wang X, Lin Y, Zhou F, Zhou L. "Sustainable decision making for joint distribution center location choice". Transportation Research Part D, 55,202-216, 2017.

[45] Golda IJ, Izdebski M. "The multi-criteria decision support in choosing the efficient location of warehouses in the logistic network". Procedia Engineering, 187, 635-640, 2017.

[46] Foroozesh N, Moghaddam RT, Mousavi SM. "A novel group decision model based on mean-variance-skewness concepts and interval-valued fuzzy sets for a selection problem of the sustainable warehouse location under uncertainty". Neural Computing and Applications, 30, 3277-3293, 2018.

[47] Mousavi SM. "A new interval-valued hesitant fuzzy pairwise comparison-compromise solution methodology: an application to cross-docking location planning". Neural Computing and Applications, 31, 5159-5173, 2018.

[48] Petrovic GS, Madic M, Antucheviciene J. "An approach for robust decision making rule generation: Solving transport and logistics decision making problems". Expert Systems With Applications, 106, 263-276, 2018.

[49] Roh SY, Shin YR, Seo YJ. "The Pre-positioned warehouse location selection for international humanitarian relief logistics". The Asian Journal of Shipping and Logistics, 34(4), 297-307, 2018.

[50] Singh RK, Chaudhary N, Saxena N. "Selection of warehouse location for a global supply chain: A case study". IIMB Management Review, 30, 343-356, 2018.

[51] You M, Xiao Y, Zhang S, Yang P, Zhou S. "Optimal mathematical programming for the warehouse location problem with Euclidean distance linearization". Computers \& Industrial Engineering, 136, 70-79, 2019. 